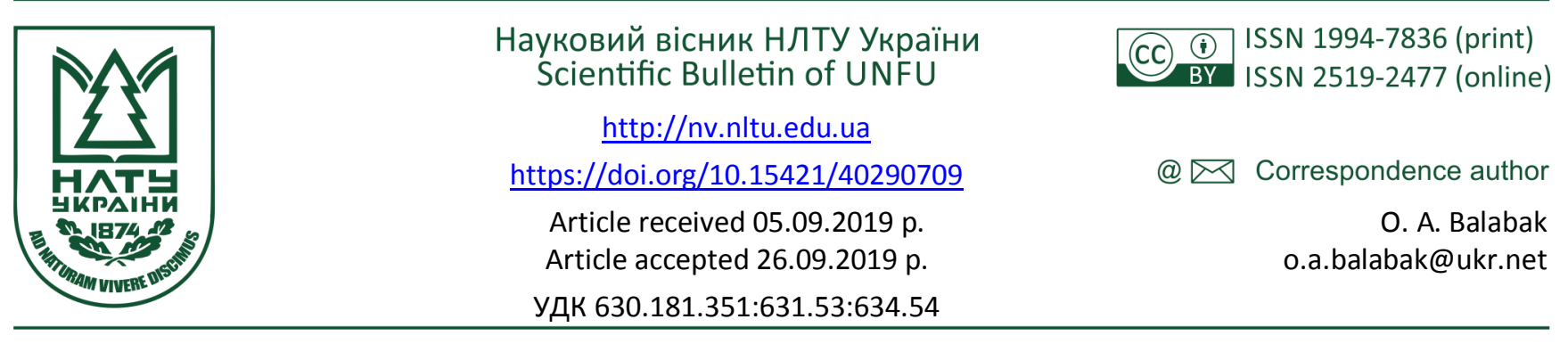

I. С. Косенко1, о. А. Балабак', А. В. Балабак ${ }^{2}$

${ }^{1}$ Національний дендрологічний парк "Софіївка" НАН України, м. Умань, Украӥна

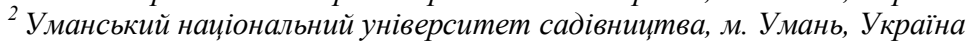

\title{
ОСОБЛИВОСТІ РОСТУ I РОЗВИТКУ РОСЛИН РОДУ CORYLUS L. ЗАЛЕЖНО ВІД ВПЛИВУ ОПТИЧНОГО ВИПРОМІНЮВАННЯ В УМОВАХ ПРАВОБЕРЕЖНОГО ЛІСОСТЕПУ УКРАЇНИ
}

\begin{abstract}
Наведено результати досліджень особливостей росту і розвитку рослин фундука в умовах насаджень. Продуктивність рослин фундука насамперед пов'язана з фотосинтетичною активністю листків. Тому формування конструкцій насаджень істотно впливає на рівень плодоношення фундука. Створення різних конструкцій в поєднанні з урахуванням сортових особливостей фундука сприяє оптимальному розміщенню рослин у насадженнях і забезпечує їхню високу врожайність. Освітлення погіршується з ростом і розвитком рослин фундука і починає впливати на рівень плодоношення на 5-6 рік після закладення насаджень. У всіх досліджуваних сортів фундука незалежно від сили росту за форми крони "Кущ", нижня частина перебуває в умовах недостатнього освітлення - 19-30\%, яке не перевищує мінімального порогу - 30 \% від відкритої поверхні. У середній частині крони рівень освітлення також був досить низький - 55-65 \%. Найбільш освітленою виявилася верхня частина крони, світловий режим якої становив - 80-94 \% від повної освітленості на відкритій поверхні. Погіршення рівня освітленості в контрольному варіанті "Кущ" відбулося через постійний ріст пагонів та їх загущення. Окрім цього, відбулося змикання рослин фундука в лінії ряду, що значно утруднювало проникнення сонячного світла в середину крони. У насадженнях із конструкціями насаджень "Вогнище", "Дерево" та "Татура" складався більш сприятливий, порівняно 3 контролем, світловий режим, що є наслідком оптимального розміщення стовбурових пагонів та гілок у кроні рослини фундука. У варіантах досліду "Вогнище", "Дерево" та "Татура" перевищення мінімального порогу освітлення у низькорослих сортів спостережено на висоті 0,5 м від поверхні грунту, що позитивно впливало на плодоношення рослин фундука під час застосування цих конструкцій насаджень. Тобто ступінь освітлення більше залежить від формування конструкцій насаджень, ніж від сортових особливостей рослин фундука, і отримані показники свідчать про значну перевагу освітленості конструкцій "Вогнище", "Дерево" та "Татура", порівняно з контролем. Найбільш розріджену схему садіння рекомендовано застосовувати для високорослих сортів фундука під час використання конструкцій насаджень "Кущ" і "Вогнище" - 6×6 м. Найщільнішу схему садіння доцільно використовувати для низькорослих сортів фундука за формування конструкції насадження "Дерево" і "Татура" $-3 \times 5$ м.
\end{abstract}

Ключові слова: фундук; сорт; конструкція насаджень; крона; освітлення; плодоношення.

Вступ. Серед асортименту перспективних лісових культур для створення насаджень особливе місце належить горіхоплідним рослинам, а саме представникам роду Corylus L., які мають харчове значення, їх використовують у створенні штучних лісових насаджень різного призначення, у садово-парковому господарстві, в різноманітних промислових галузях та в розширенні селекційно-генетичного фонду під час створення лісонасінної бази (Makhno, 2014).

Одним з основних чинників росту, розвитку та плодоношення горіхоплідних рослин $є$ сонячна радіація. Сонячне світло безпосередньо впливає на ріст і розвиток рослин фундука в процесі розмноження та подальшого їх росту і плодоношення в умовах насаджень

\section{(Gökirmak et al., 2009).}

Інтенсивний розвиток кущової порослі призводить до притінення бічних пагонів i, як наслідок, до зниження врожаю. Окрім цього, внаслідок сильного росту молодих пагонів, кущі сильно загущуються, що призводить до низької фертильності та життєздатності пилку, слабкого запилення, а також до розвитку грибкових захворювань на плодах та пагонах (Nekrasov et al., 1982).

У разі загущеності кущів більше чим на 15-25 пагонів спостерігаємо майже повний перехід плодоношення на периферійну частину рослини фундука. Тобто продуктивна частина знижується більше, ніж у два рази, тому що внутрішня частина рослини фундука займає

\section{Інформація про авторів:}

Косенко Іван Семенович, д-р біол. наук, професор, директор, член-кореспондент HAHУ. Email: ndp.sofievka@jmail.com; https://orcid.org/0000-0003-2085-7477

Балабак Олександр Анатолійович, канд. с.-г. наук, ст. наук. співробітник, завідувач відділу генетики, селекції та репродуктивної біології рослин. Email: o.a.balabak@ukr.net; https://orcid.org/0000-0002-7435-9783

Балабак Алла Василівна, канд. с.-г. наук, доцент, кафедра екології та безпеки життдіяльності. Email: A.V.balabak@ukr.net Цитування за ДСтУ: Косенко І. С., Балабак О. А., Балабак A. B. Особливості росту і розвитку рослин роду Соrylus L. залежно від впливу оптичного випромінювання в умовах Правобережного Лісостепу України. Науковий вісник НЛтУ України. 2019, т. 29, № 7. С. 42-44.

Citation APA: Kosenko, I. S., Balabak, O. A., \& Balabak, A. V. (2019). Features of Growth and Development of the Genus Corylus L. Plants Depending on the Optical Radiation Influence in the Right-Bank Forest-Steppe Zone of Ukraine. Scientific Bulletin of UNFU, 29(7), 42-44. https://doi.org/10.15421/40290709 
понад $70 \%$, а зовнішня - тільки 30 \% відповідно (Коsenko et al., 2019).

У промисловій культурі фундук вирощують як у кущовій, так і в деревоподібній формах. На грунтах із високим вмістом гумусу та оптимальним волого забезпеченням, де рослини фундука розміщуються 3 площею живлення більше ніж 35-40 м² (7-8 м×5-6 м), під час визначення форми і структури кущів залишені багато- річні пагони (4-6 шт.) орієнтують у нахиленому положенні (Kosenko et al., 2016).

Також застосовують інші системи формування крони фундука: типу "Вогнище", "Канкан", "Дерево", "Татура", а також рослини без формування - "Кущова". При цьому структура рослин за різного формування має відповідні показники (табл. 1).

Табл. 1. Структура, площа живлення та врожайність фундука з різною формою рослин у віці 12 років (Мakhno, 2014).

\begin{tabular}{|c|c|c|c|c|c|}
\hline Система формування & Площа живлення, м & $\begin{array}{c}\text { Кількість рослин } \\
\text { на 1 га, шт. }\end{array}$ & $\begin{array}{c}\text { Кількість стовбурів } \\
\text { на рослині, шт. }\end{array}$ & $\begin{array}{c}\text { Кількість стовбурів } \\
\text { на 1 га, шт. }\end{array}$ & Урожай, ц/га \\
\hline "Кущова" & $6 \times 5$ & 333 & 8 & 2664 & 9,0 \\
\hline "Вогнище" & $6 \times 5$ & 333 & 6 & 1998 & 10,0 \\
\hline "Канкан" & $6 \times 5$ & 333 & 4 & 1332 & 9,5 \\
\hline "Дерево" & $6 \times 2$ & 833 & 1 & 833 & 13,5 \\
\hline "Татура" & $6 \times 3$ & 555 & 2 & 1100 & 13,7 \\
\hline
\end{tabular}

Найбільш інтенсивними системами формування конструкцій насаджень $є$ "Вогнище", за якої в кожну підготовлену садивну яму висаджують 5-6 рослин, що надалі ростуть на власних коренях і мають вигляд скелетних гілок, та "Татура", яка базується на висаджуванні 2-х рослин в одну садивну яму з нахилом цих рослин у протилежні боки (Kosenko et al., 2008).

Мета нашої роботи - вивчити особливості росту і розвитку рослин роду Corylus L. залежно від впливу оптичного випромінювання в умовах Правобережного Лісостепу України.

Матеріали і методи дослідження. Дослідження проводили в насадженнях Дослідно-виробничої дільниці НДП "Софіївка" НАН України. Використовували типи формування крони - "Вогнище", "Дерево", "Татура", а також рослини без формування - "Кущова". Надходження сумарної сонячної радіації до різних ділянок крони дерев фундука визначали в період інтенсивного росту горіхів (перша декада серпня). Усі спостереження були проведені в сонячні безхмарні дні. Надходження сумарної сонячної радіації в різні ділянки крони визначали за методикою В. В. Хроменка. Для вимірювання в кожному варіанті відбирали рослини фундука, типові за біометричними показниками (Khromenko,1987).

Результати дослідження. Ступінь освітлення знаходиться у прямій залежності від формування конструкцій насаджень і сили росту рослин фундука. Освітлення погіршується з ростом і розвитком рослин фундука і починає впливати на рівень плодоношення на 5-6-й рік після закладки насаджень. У низькорослих сортів фундука (Футкурамі і Черкеський-2) за форми крони "Кущ" нижня частина перебуває в умовах недостатнього освітлення - 19-30\%, яке не перевищує мінімального порогу - 30 \% від відкритої поверхні. У се- редній частині крони рівень освітлення також був досить низький $-55-65 \%$. Найбільш освітленою виявилася верхня частина крони, світловий режим якої становив - 80-94 \% від повної освітленості на відкритій поверхні. Зона зі зниженим рівнем освітлення під час формування конструкції "Кущ" становила близько 70 \%.

Внаслідок формування конструкції насадження "Вогнище" в нижній частині крони також спостерігали недостатнє освітлення - 20-45\%, у середній частині 60-80\% і найбільший відсоток від повної освітленості на відкритій поверхні був у верхній частині - 90-94 \%. У цьому варіанті досліду зона зі зниженим рівнем освітлення становила близько $40 \%$

За формування конструкції "Дерево" спостерігали високий рівень освітленості, який становив у нижній частині крони 20-45 \%, у середній - 60-80\% та у верхній - 90-94 \% - зона зі зниженим рівнем освітлення становила близько $30 \%$.

Найвищий рівень освітленості спостерігали під час формування конструкції насаджень "Татура", який становив в нижній частині близько $30 \%$, у середній - 70$80 \%$, у верхній - 90-94 \% але при цьому зона зі зниженим рівнем освітлення становила близько $20 \%$.

Погіршення рівня освітленості в контрольному варіанті "Кущ" відбулося через постійний ріст пагонів та їх загущення. Окрім цього, відбулося змикання рослин фундука в лінії ряду, що значно утруднювало проникність сонячного світла в середину крони.

У насадженнях із конструкціями насаджень "Вогнище", "Дерево" та "Татура" складався більш сприятливий, порівняно з контролем, світловий режим, що $\epsilon$ наслідком оптимального розміщення стовбурових пагонів та гілок у кроні рослини фундука (рисунок).

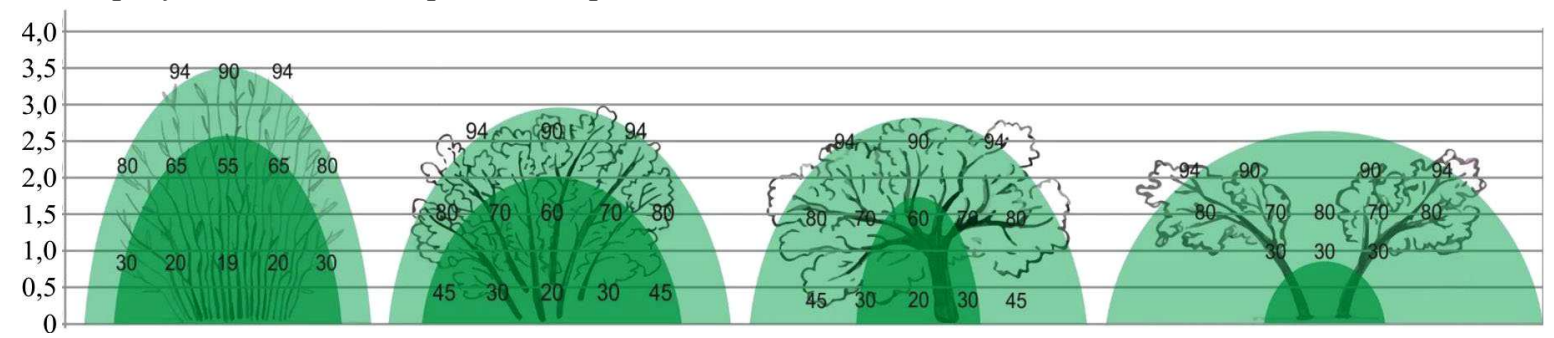

Рисунок. Освітлення крони шестирічних рослин фундука сорту фундука Лозівський шароподібний залежно від конструкції насаджень, ділянку закладено в 2010 р., схема садіння 6х6 м, 2014-2016 рр.: а) "Кущ"; б) "Вогнище"; в) "Дерево"; г) "Татура"

У середньорослих (Лозівський шароподібний, Софіївський 15) та високорослих (Україна-50 та Софіївський 2) сортів фундука під час утримання та формування конструкцій насаджень "Кущ", "Вогнище", "Дерево" і
"Татура", рівень освітлення також був вищий внаслідок формування малогабаритної крони. Так, у нижньому, середньому і верхньому ярусах досліджуваних рослин фундука відсоток від повної освітленості на відкритій 
поверхні повністю збігався з аналогічними показниками низькорослих сортів. Конструкції насаджень середньорослих і високорослих сортів фундука відрізнялися тільки силою росту і діаметром крони, що призводило у варіантах досліду "Кущ" i "Вогнище" до змикання крони та потребувало ретельнішого підбору схем садіння.

У варіантах досліду "Вогнище", "Дерево" та "Татура" перевищення мінімального порогу освітлення у низькорослих сортів спостерігали на висоті 0,5 м від поверхні грунту, що позитивно впливало на плодоношення рослин фундука під час застосування цих конструкцій насаджень. У середньорослих і високорослих сортів фундука перевищення мінімального порогу освітлення також спостерігали на висоті 0,5 м від поверхні грунту у варіантах досліду "Вогнище" та "Дерево", а під час формування "Татура" - на висоті від 1 м від поверхні грунту. Тобто ступінь освітлення більше залежить від формування конструкцій насаджень, ніж від сортових особливостей рослин фундука. Отримані показники свідчать про значну перевагу освітлення конструкцій "Вогнище", "Дерево" та "Татура", порівняно $з$ контролем.

Від сортових особливостей та застосованих конструкцій насаджень залежить підбір схем садіння рослин фундука в умовах насаджень (табл. 2).

Табл. 2. Рекомендовані схеми садіння під час застосування різних конструкцій насаджень фундука, м

\begin{tabular}{|c|c|c|c|c|}
\hline \multirow{2}{*}{$\begin{array}{c}\text { Сортова } \\
\text { особливість }\end{array}$} & \multicolumn{4}{|c|}{ Схема садіння за різних конструкцій } \\
\cline { 2 - 5 } & "Кущ" & "Вогнище" & "Дерево" & "Татура" \\
\hline Високорослі & $6 \times 6$ & $6 \times 6$ & $4 \times 6$ & $4 \times 6$ \\
\hline Середньорослі & $6 \times 6$ & $6 \times 6$ & $3 \times 6$ & $3 \times 6$ \\
\hline Низькорослі & $4 \times 6$ & $4 \times 6$ & $3 \times 5$ & $3 \times 5$ \\
\hline
\end{tabular}

Найбільшу схему садіння рекомендували застосовувати для високорослих сортів фундука під час використання конструкцій насаджень "Кущ" і "Вогнище" - відповідно $6 \times 6$ м. Найменшу схему садіння доцільно використовувати для низькорослих сортів фундука за фор- мування конструкції насадження "Дерево" і "Татура" відповідно $3 \times 5$ м.

Висновки. Найвищий рівень освітленості спостерігали під час формування конструкції насаджень "Татура", який становив у нижній частині близько $30 \%$, у середній - 70-80 \%, у верхній - 90-94 \% але при цьому зона зі зниженим рівнем освітлення становила близько 20 \%. Ступінь освітлення більше залежить від формування конструкцій насаджень, ніж від сортових особливостей рослин фундука. Отримані показники свідчать про значну перевагу освітлення конструкцій "Вогнище", "Дерево" та "Татура", порівняно з контролем.

\section{Перелік використаних джерел}

Gökirmak, T., Mehlenbacher, S. A., \& Bassil, N. V. (2009). Characterization of European hazelnut (Corylus avellana) cultivars using SSR markers. Genetic resources and crop evolution, 56(2), 147172. https://doi.org/10.1007/s10722-008-9352-8

Khromenko, V. V. (1987) On the methodology for studying the light regime in the crown of fruit trees. Improving the technology during intensification of fruit production in the Non-Chernozem zone, 2835. [In Russian].

Kosenko, I. S. (Ed.), Opalko, A. I., \& Opalko, O. A. (2008) Hazelnut: Applied Genetics, Breeding, the Methods of Propagation and Production. Kyiv: Naukova Dumka, 256. [In Ukrainian].

Kosenko, I. S., Opalko, A. I., Balabak, O. A., \& Shulga, S. M. (2016). Corylus spp. genetic resources use in hazelnuts Corylus domestica Kos. et Opal. improvement. Autochthonous and Alien Plants, 12, 120-136. [In Ukrainian].

Kosenko, I. S., Opalko, A. I., Balabak, O. A., Opalko, O. A., \& Balabak, A. V. (2019). Hazelnut (Corylus domestica Kos. et Opal.) research and breeding at NDP "Sofiyivka" of NAS of Ukraine. Temperate Horticulture for Sustainable Development and Environment. Ecological aspects [Eds.: L. I. Weisfeld, A. I. Opalko, S. A. Bekuzarova]. Oakville; Waretown: Apple Academic Press, Vol. 13, 237-267.

Makhno, V. G. (2014). Application of the genus Corylus in ornamental and commercial gardening. Subtropical and ornamental horticulture, 50, 232-235. [In Russian].

Nekrasov, Y., \& Romanovych, Y. (1982). Comparative characteristics of the quality of pollen and seeds of some herbaceous introducents. Bullatin main botanical garden, 123, 31-33. [In Russian].

I. S. Kosenko1, O. A. Balabak1, A. V. Balabak 2

${ }^{I}$ National Arboretum "Sofiyivka", NAS Ukraine, Uman, Ukraine

${ }^{2}$ Uman National University of Horticulture, Uman, Ukraine

\section{FEATURES OF GROWTH AND DEVELOPMENT OF THE GENUS CORYLUS L. PLANTS DEPENDING ON THE OPTICAL RADIATION INFLUENCE IN THE RIGHT-BANK FOREST-STEPPE ZONE OF UKRAINE}

The results of studies of the characteristics of the growth and development of filbert plants in the conditions of plantations are presented. The productivity of filbert plants is primarily connected to the photosynthetic activity of the leaves. Therefore, the formation of plantation structures affects significantly the level of fruiting of the filbert. The creation of various structures, in combination with the varietal characteristics of filberts considering, contributes to the optimal placement of plants in the stands and ensures their high productivity. Illumination declines with the growth and development of filbert plants and begins to affect the fruiting level on the 5th-6th year after plantation. The lower part of all the studied filbert varieties, regardless of the growth force, with the shape of the crown "The Bush" is in the conditions of insufficient illumination - 19-30\%, which does not exceed the minimum limit $-30 \%$ of the open surface. In the middle part of the crown, the illumination level was also quite low $-55-65 \%$. The upper part of the crown turned out to be the most illuminated, the light regime of that was $80-94 \%$ of the total illumination on an open surface. The deterioration of the illumination level in the control variant "The Bush" was due to the regular growth of shoots and their thickening. In addition, the filbert plants closed in a row line, which greatly impeded the penetration of sunlight into the crown. In the stands of the structures "The Fire", "The Tree" and "Tatura", a more favourable light regime was created in comparison with the control, what is a consequence of the optimal placement of stem shoots and branches in the crown of the filbert plant. In the variants of the "The Fire", "The Tree" and "Tatura" experiments, the excess of the minimum limit of illumination in low-growing varieties was observed at a height of $0.5 \mathrm{~m}$ above the soil surface, what positively affected the fruiting of filbert plants when using these plantation structures. That is, the degree of illumination depends more on the formation of plantation structures than on the varietal characteristics of filbert plants, and the obtained data indicate a significant advantage of lighting the structures "The Fire", "The Tree" and "Tatura" compared with the control. The sparsest plantation pattern is recommended for tall varieties of filbert when using the plantation structures "The Bush" and "The Fire" $-6 \times 6 \mathrm{~m}$. It is advisable to use the densest plantation scheme for lowgrowing varieties of filberts when using the plantation structures "The Tree" and "Tatura" $-3 \times 5 \mathrm{~m}$.

Keywords: filbert; variety; plantation structure; crown; illumination; fruiting. 